Економічні науки: збірник наукових праць Луиького національного технічного університету. Серія "Регіональна економіка". Випуск 17 (67). Редкол.: відп. ред. к.е.н., професор І.В. Кривов’язюк. Луцьк: ІВВ Луцького НТУ, 2020. 348 с.

УДК 338.2

Щьокіна Є.Ю., к.е.н., доцент

Черепанова Н.О., ст. викл.

Гужва O.А.

Одеський національний політехнічний університет

\title{
ФІНАНСОВА ГРАМОТНІСТЬ ЯК ЗАПОРУКА СОЦІАЛЬНОГО ТА ЕКОНОМІЧНОГО РОЗВИТКУ ДЕРЖАВИ
}

У статті розглянуто сутність фінансової грамотності населення як фактор економічного та соціального розвитку та добробуту держави; виділено загальні аспекти даного терміну. Визначено роль держави і спеціальних інститутів у процесі підвищення рівня фінансової грамотності населення. Представлено схему зовнішнього середовища держави, яка впливає на необхідність обов'язкової фінансової грамотності населення. Запропоновано систему просування та розповсюдження фінансової грамотності населення, яка $\epsilon$ запорукою успішності населення та соціального і економічного розвитку держави в цілому.

Ключові слова: фінансова грамотність, економічний розвиток, соціальний розвиток, система просування фінансової грамотності, фінансова обізнаність, розвиток держави.

\section{Shchokina E., Cherepanova N., Guzhva O. FINANCIAL LITERACY AS A GUARANTEE OF SOCIAL AND ECONOMIC DEVELOPMENT OF THE STATE}

Financial literacy plays an important role in the social and economic development of the state and its place in the world economic arena. In today's world, citizens with their personal finances become active participants in socio-economic, including financial, relations, so high economic development can be achieved through financial literacy of the population, because society achieves the greatest economic success when citizens have developed skills of acceptance responsible and conscious decisions in the financial sphere.

The article considers the essence of financial literacy of the population as a factor of economic and social development and welfare of the state; highlighted the general aspects of this concept.. The role of the state and special institutions in the process of raising the level of financial literacy of the population is determined. The aspect of financial education, which is necessary for any person in modern society, is indicated. It is noted that the state has a fairly large list of means of influencing the population both in the long run and in case of emergencies. The scheme of the 
Економічні науки: збірник наукових праць Луиького національного технічного університету. Серія "Регіональна економіка". Випуск 17 (67). Редкол.: відп. ред. к.е.н., професор І.В. Кривов’язюк. Луцьк: ІВВ Луцького НТУ, 2020. 348 с.

external environment of the state which influences necessity of obligatory financial literacy of the population is presented. It is noted that in many developed countries the increase of financial literacy is an element of public policy and proposed a system of promotion and dissemination of financial literacy, which is the key to success and social and economic development of the state as a whole.

Key words: financial literacy, economic development, social development, system of financial literacy promotion, financial awareness, state development.

\section{Щёкина Е.Ю., Черепанова Н.А., Гужва А.А. ФИНАНСОВАЯ ГРАМОТНОСТЬ КАК ЗАЛОГ СОЦИАЛЬНОГО И ЭКОНОМИЧЕСКОГО РАЗВИТИЯ ГОСУДАРСТВА}

В статье рассмотрена сущность финансовой грамотности населения как фактор экономического и социального развития и благосостояния государства; выделены общие аспекты данного понятия. Представлена схема внешней среды государства, которая влияет на необходимость обязательной финансовой грамотности населения. Отмечено, что во многих развитых странах повышение финансовой грамотности является элементом государственной политики; предложена система продвижения и распространения финансовой грамотности населения, которая является залогом успешности населения и социального и экономического развития государства в целом.

Ключевые слова: финансовая грамотность, экономическое развитие, социальное развитие, система продвижения финансовой грамотности, финансовая осведомленность, развитие государства.

\section{Постановка проблеми у загальному вигляді i iї 3} важливими науковими та практичними завданнями. Стрімке поширення фінансових відносин на всі сфери життєдіяльності людини потребують належного рівня фінансової обізнаності громадян. Розвиток фінансової сфери $\epsilon$ одним із приоритетних завдань держави на сучасному етапі економічного розвитку. Саме фінансова грамотність та обізнаність населення в фінансовій сфері призведе до вирішення соціально-економічних проблем.

Аналіз останніх досліджень, у яких започатковано вирішення проблеми. Питання фінансової грамотності $\epsilon$ об'єктом наукових досліджень багатьох вітчизняних та зарубіжних вчених, серед яких: Р. Бонд [1], Н. Хілл, А. Луасарді, 
Економічні науки: збірник наукових праць Луиького національного технічного університету. Серія "Регіональна економіка". Випуск 17 (67). Редкол.: відп. ред. к.е.н., професор І.В. Кривов'язюк. Луиьк: ІВВ Луцького НТУ, 2020. 348 с.

О. Мітчелл, Т. Смовженко [2], М. Овчинников, Г. Шахназарян [3], Л. Стахович та ін. Науковці А. Зеленцова, Р. Бонд, О. Куценко, Н. Лозицька у своїх роботах досліджують стан фінансової грамотності населення в Україні й визначають необхідність іiі підвищення. Незважаючи на широке коло публікації в означеній проблематиці, питання фінансової грамотності населення сьогодні набувають надзвичайної актуальності.

Метою статті $є$ дослідження фінансової грамотності як запоруки соціального та економічного розвитку держави, виявлення актуальних проблем, що призводять до низького рівня фінансової грамотності громадян та окреслення можливих шляхів її підвищення.

Виклад основного матеріалу дослідження 3 повним обгрунтуванням отриманих наукових результатів. В умовах короновірусної епідемії і пов'язаних з нею карантинних заходів суттєве навантаження лягає на державу, яка повинна забезпечити населення країни необхідними умовами існування. Це ускладнюється тим, що процес має загальносвітовий характер і охопив всі країни. Запобіжними заходами стало закриття кордонів, у результаті чого кожна країна залишилася на самоті зі всіма своїми ресурсами, надбаннями і проблемами. Тому, одним з можливих варіантів подальшого розвитку країн буде суттєва трансформація структури споживання населення, 3 орієнтацією на власні можливості i традиції, як спосіб виживання нації в умовах можливої ізоляції.

В таких умовах велике значення набуває зміна ролі держави і державного сектору економіки. Можливість держави акумулювати значні ресурси значною мірою впливає на швидкість мобілізації всієї національної економіки, перерозподіл пріоритетів у суспільстві [4]. Під час пандемії виникла ситуація, яка примусила населення обмежити всі види спілкування, в тому числі і у фінансовій сфері. Більшість операцій рекомендовано проводити безготівково, віддаючи перевагу інтернет-банкінгу, що призводить до проблеми недостатньої фінансової грамотності і інформованості. 
Економічні науки: збірник наукових праць Луиького національного технічного університету. Серія "Регіональна економіка". Випуск 17 (67). Редкол.: відп. ред. к.е.н., професор І.В. Кривов'язюк. Луиьк: ІВВ Луцького НТУ, 2020. 348 с.

Особливо це стосується частини населення, яка не володіє навичками використання комп'ютерів і інтернет ресурсів.

Фінансові послуги стають дедалі різноманітнішими, відповідно споживачам все складніше орієнтуватися та використовувати нові фінансові продукти на ринку. Фінансова грамотність передбачає сукупність знань про фінансові інститути i пропонованих ними продуктах, вміння їх застосовувати, приймати рішення з урахуванням всіх наявних ризиків і можливих наслідків. Фінансова грамотність допомагає зрозуміти ключові фінансові поняття, швидко орієнтуватися у вирі фінансових можливостей та у послугах і продуктах, роботи вибір відповідних фінансових інструментів та розпізнавати загрози. У підвищенні рівня фінансової грамотності населення та створення необхідних умов для організації та проведення різноманітних освітніх програм фінансово-економічного спрямування населення у фінансовій сфері повинна займатися держава, яка бере зобов'язання щодо надання ринковій економіці соціальної спрямованості. Держава має достатньо великий перелік засобів впливу на населення як у довгостроковому періоді, так i y разі екстраординарних ситуацій, коли можна задіяти такі інструменти, як засоби масової інформації (ЗМI), інтернет ресурси, тощо (рис 1).

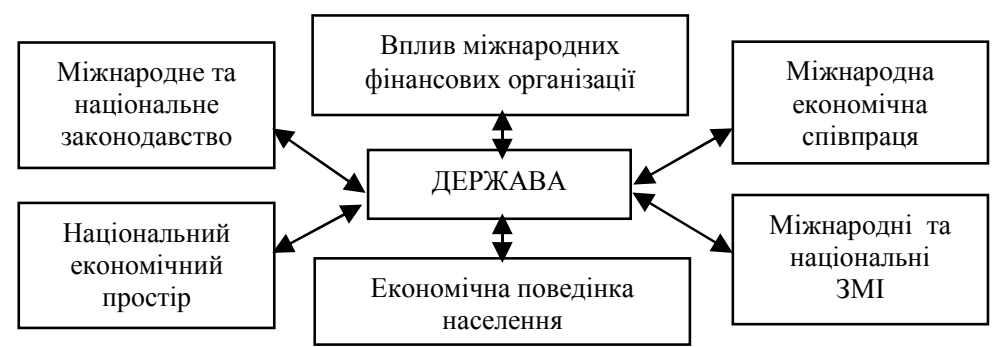

Рис 1 - Зовнішнє середовище держави, яке впливає на необхідність обов'язкової фінансової грамотності населення (авторська розробка) 
Економічні науки: збірник наукових праць Луиького національного технічного університету. Серія "Регіональна економіка". Випуск 17 (67). Редкол.: відп. ред. к.е.н., професор І.В. Кривов’язюк. Луцьк: ІВВ Луцького НТУ, 2020. 348 с.

У багатьох розвинених країнах підвищення фінансової грамотності є елементом державної політики. Рішенням завдань в цьому напрямку займаються спеціальні державні відомства або організації, що фінансуються державою. В Україні просування шляхів до фінансової грамотності знаходиться в початковій стадії, що потребує дієвої системи просування та розповсюдження фінансової грамотності населення та реалізації інформаційно-освітніх програм (рис. 2).

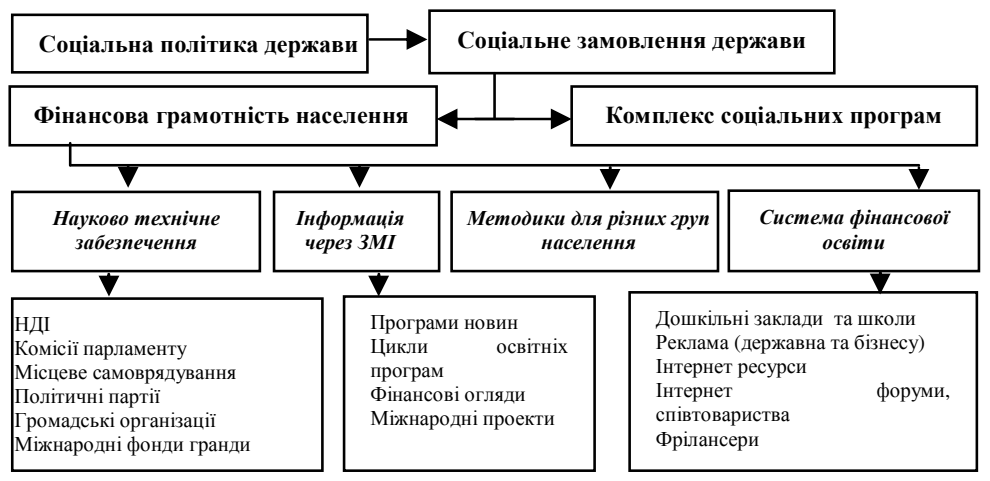

Рис 2. Система просування та розповсюдження фінансової грамотності населення (авторська розробка)

Сьогодні суттєво зростає роль і відповідальність держави у формуванні i здійсненні соціальної політики в країні, змінюються національні стандарти соціального замовлення держави 3 урахуванням нагальних і довгострокових потреб суспільства [4]. З'являється необхідність продуманої та контрольованої системи просування знань у фінансовій сфері. В Україні на сьогодні склався недостатній для сучасного способу життя рівень фінансової грамотності населення, тому існує ряд проблем, які можна подолати саме використовуючи відповідні програми фінансової інформованості: низький рівень мобільності населення; високий рівень зв'язку 3 місцем народження і проживання родини; боязнь жити у кредит; не 
Економічні науки: збірник наукових праць Луиького національного технічного університету. Серія "Регіональна економіка". Випуск 17 (67). Редкол.: відп. ред. к.е.н., професор І.В. Кривов'язюк. Луиьк: ІВВ Луцького НТУ, 2020. 348 с.

сформоване усвідомлення самостійності молоді; тиск стереотипів суспільної поведінки.

Для успішного втілення державного плану розвитку фінансової грамотності в життя, необхідна послідовна, але в той же час методологічно різнобічна програма досліджень, такі як: фундаментальні дослідження, пов'язані з програмою навчання особистих фінансів i створенням технологій для такого навчання; термінові дослідження, націлені на розробку нових форм освітнього програмного забезпечення, інформаційних матеріалів та педагогічних методів та ін.

Висновки. Від загального рівня фінансової грамотності населення держави багато в чому залежить іï соціальний та економічний розвиток. В сучасних умовах інформаційного суспільства, створення необхідних умов та впровадження програм різноманітних освітніх програм фінансовоекономічного спрямування населення у фінансовій сфері повинно стати стратегічним напрямом державної політики, що сприятиме підвищенню рівню життя громадян та $є$ запорукою соціального і економічного розвитку держави в цілому.

\section{Список бібліографічного опису}

1. Фінансова грамотність та обізнаність в Україні: факти та висновки / Р. Бонд, О. Куценко, Н. Лозицька. К.: USAID FINREP, 2010. 36 с.

2. Смовженко Т.С., Кузнєцова А.Я. Фінансова грамотність населення та iii вплив на розвиток економіки України. Регіональна економіка. 2013. № 2(68). C. 34-42.

3. Шахназарян Г.Э. Финансовая грамотность населения в свете современных тенденций развития образования. Финансы и кредит. 2008. № 20 (308). C. 51-58.

4. Черепанова Н.О. Сучасні економічні системи i загострення глобальних проблем суспільства. Актуальні наукові дослідження в сучасному світі // Журнал Переяслав, 2020. Вип. 7(63), ч. 3143 с. С. 132-136. Режим доступу до журн.: http://elibrary.ru/title about.asp?id=5841

5. Щьокіна Є.Ю. Парадигма інноваційного розвитку в умовах ринкової трансформації. Східна Європа: економіка, бізнес та управління. Електронний науково-практичний фаховий журнал / ДВНЗ «Придніпровська державна академія будівництва та архітектури». м. Дніпро. 2019. С. 411-417

\section{References}

1. Bond, R. Finansova hramotnist' ta obiznanist' $\mathrm{v}$ Ukrayini: fakty ta vysnovky / R. Bond, O. Kutsenko, N. Lozyts'ka. K.: USAID FINREP, 2010. 36 p. [in Ukrainian] 
Економічні науки: збірник наукових праць Луиького національного технічного університету. Серія "Регіональна економіка". Випуск 17 (67). Редкол.: відп. ред. к.е.н., професор І.В. Кривов’язюк. Луцьк: ІВВ Луцького НТУ, 2020. 348 с.

2. Smovzhenko T.S., Kuznyetsova A.Ya. Finansova hramotnist' naselennya ta yiyi vplyv na rozvytok ekonomiky Ukrayiny. Rehional'na ekonomika. 2013. № 2(68). p. 34-42. [in Ukrainian]

3. Shakhnazaryan H.E. Finansova hramotnist' naselennya $v$ svitli suchasnykh tendentsiy rozvytku osvity. Finansy i kredyt. 2008. №20 (308). p. 51-58. [In Russsian]

4. Cherepanova N.O. Suchasni ekonomichni systemy i zahostrennya hlobal'nykh problem suspil'stva. Aktual'ni naukovi doslidzhennya v suchasnomu sviti // Zhurnal Pereyaslav, 2020. - Vyp. 7(63), ch. 3. p. 132-136 [in Ukrainian]

5. Shch'okina Ye.Yu. Paradyhma innovatsiynoho rozvytku v umovakh rynkovoyi transformatsiyi. Skhidna Yevropa: ekonomika, biznes ta upravlinnya. Elektronnyy naukovo-praktychnyy fakhovyy zhurnal / DVNZ «Prydniprovs'ka derzhavna akademiya budivnytstva ta arkhitektury». Dnipro. 2019. p. 411-417 [in Ukrainian] 